\title{
Research on the Impact of Tax Reform on the Tax Burden of Logistics Enterprises
}

\author{
Yong $\mathrm{Liu}^{1}$, Yumin $\mathrm{Li}^{1}$, and Xianshun Wang ${ }^{1}$ \\ ${ }^{1}$ Administrative Engineering College, Zhengzhou University, NO.100 Kexue Roadt, Zhengzhou, China \\ 11204745292@qq.com, 1li.yu.min.com,364859531@qq.com
}

Keywords: logistics industry, tax, value-added tax, replace the business tax with a value-added tax

\begin{abstract}
Logistics is the artery of national economy, the connecting link between the various parts of the national economy, the premise of ongoing production process, and also the realization of commodity circulation material foundation (Jiehe Cui, 2010). Logistics constructs a large network of transport by railway, highway, aviation, waterways, pipelines in the world, goods continue to flow in the large transportation network around the world, which supports normal operation of industries and enterprises. In the 21st century, China's economic development maintains rapid and healthy situation, along with the electronic commerce developing of China, logistics industry faces with important development opportunities. Especially rural logistics and retail logistics will continue to keep hot, logistics enterprise development prospects can be described as a bright future. This tax reform has brought the key development opportunities for logistics. In the long run, it is bound to lay a solid foundation for the development of the logistics industry.
\end{abstract}

\section{INTRODUCTION}

The tax reform on the logistics enterprises had a great impact on the logistics enterprises, which is conducive to logistics enterprises to reduce tax burden and promote the logistics enterprises to upgrade their technology and equipment. This paper mainly discusses the impact of the tax reform on the logistics industry and the problems in the implementation process, discusses the causes of these problems and the impact on the logistics industry, and puts forward countermeasures to the logistics industry according to these problems. In the process of policy implementation, according to the feedback situation, the paper puts forward some suggestions.

In March 2009, the State Council issued a "logistics industry restructuring and revitalization plan", the "manufacturing and logistics industry linkage development project" included in one of the nine projects." On the promotion of the healthy development of the logistics industry policy measures" clearly called "to effectively reduce the tax burden of logistics enterprises." This paper hopes to analyze the problems in the pilot and find out the reasons and put forward some useful suggestions.

\section{REVIEW OF LITERATURE}

Since the implementation of the tax reform in the logistics industry, various studies have sprung up like mushrooms. Dongming Xia believes that in the new situation of tax reform, the original tax scheme will no longer be used, and the logistics enterprises should adjust their tax planning plan according to the new policy in a timely manner, so as to maximize the interests of enterprises (Dongming Xia, 2014). Liming He believes that "nine countries" has played a huge role in reducing the cost of commodity circulation and the tax burden of logistics enterprises (Liming He, 2011). Xi Feng believes that some of the higher proportion of the cost cannot be deducted, and value-added tax rates are high, which results in higher tax burden (Xi, Feng, 2012). Jianping Wang believes that the tax burden presents the characteristics of the overall increase of the industry, especially in the transportation industry, and the logistics assistance industry. The increase in tax burden is mainly due to the lack of comprehensive tax system design, which reflected in the limited range of VAT deduction and the high tax rate (Jianping, Wang, 2014).

From the development of value-added tax on the value-added tax, the concept prototype was originally proposed by C.F.Siemens in 1921. Oskar Henkow believes which the tax system is reasonable or not will affect the operation of social supply chain, and reasonable tax system is conducive to the effective operation of social supply chain (Oskar, Henkow, Andreas Norrman, 2011). Anthony, Chin, Hong, Jun, Jie believe that the local tax policy and land policy will affect the location decision-making of logistics enterprises. They suggest that the local government should consider its impact on the supply chain when formulating policies (Anthony, D.Ross, Hamieda, Parker, M., Mar, Benavides-ESpinosa, Cornelia, Droge, 2012).

\section{PROBLEM EXISTING IN THE PERIOD OF BUSINESS TAX}

The business tax is a tax on the amount of the business in which the unit and individual who provide taxable services, transfer of intangible assets or sell real estate in China. Business tax make a significant contribution to the national financial revenue, but with the economic and social development, business tax also exposed some problems.

\subsection{Serious Problem of Repeated Taxation}

The problem of repeated taxation in the logistics industry has existed for a long time, which exists mainly in the sales tax. Due to the business tax is collected on all the turnover of the business, which cannot offset the 
input tax, causing serious double taxation. The repeated taxation on business tax results in an additional increase in urban construction tax and education fees. Due to the small division of labor Railway industry, repeated taxation problem is more serious.

\subsection{Different Business Tax Rates}

The problem that logistics industry business tax rate is not uniform exists long ago. For the logistics industry, the business tax rate is $3 \%$, while warehousing and other services in accordance with the $5 \%$ business tax rate. The development trend of modern logistics industry should be integrated, according to different tax rates, not only to cause trouble in logistics business financial management, but also hindered the integration of the logistics industry. At the same time, with regard to the application of the tax rate, the transport and distribution are respectively levied at a rate of $3 \%$ and $5 \%$. However, the boundaries of transport and distribution are not clear, and there is a problem in the classification of the business.

\subsection{The Problem of Invoice}

Logistics industry invoices are mainly administrative fees invoices, general transport invoices, service invoices three categories, which is a total of 20 kinds. In addition to the different requirements and standards of various invoices, it results in the problem of logistics industry about invoices. According to the provisions of the tax law, warehousing, agents, etc. should be issued by the tax rate of $5 \%$ of the service invoice, and the transport industry issued a tax rate of $3 \%$ of the transport invoices. As the logistics and transport industry tax rate is lower than the service industry. In order to pay less business tax, all the business of logistic companies are issued into transport invoices. Cargo companies need to be certified as self-billing taxpayers if they want to issue invoices. if not, they need tax department to issue invoice on behalf of them. but the invocie that issued by tax department can not be deducted VAT, thus greatly increasing the tax burden of enterprises.

\subsection{Unclear Policy of Variable Levy}

Business Tax Taxation is a way to solve the repeated taxation of the business tax in the logistics industry. But the policy of variable levy also has its shortcomings. First of all, enterprises who tranfer transport business or warehousing business to other enterprises and the price charged by the business can use variable levy. But for those who do not have the qualification of variable levy, the transport business can be in accordance with the variable levy, but the warehousing and other business can only be in accordance with the full collection of business tax, which caused unfair competition. When logistics enterprises entrust their business to a variety of modes of transportation, the proportion of the commission can be taxed differently, which is not clearly defined in the policy.

\section{BASIC SITUATION AND ACTUAL EFFECT OF TAX REFORM IN LOGISTICS INDUSTRY}

\subsection{The Expected Targets of Tax Reform}

The implementation of "camp to increase" policy is a huge institutional innovation of our tax system. This is not just a change of taxes, but a change of the whole society. The purpose of the tax reform is to solve the previous repeated taxation, improve the tax system, and to reduce corporate tax burden, and promote economic restructuring. For the logistics industry, the implementation of tax reform can effectively promote the professional, normalized development of the logistics industry. After tax reform, due to the purchase of new equipment can be deducted, some low-end logistics companies will ride this opportunity to buy new equipment in order to upgrade their business level, which will make logistics industry better.

\subsection{The Basic Situation of Experimental Unit}

The pilot work of tax reform is carried out in batches. In January 1, 2012, the pilot of tax reform started in Shanghai. From the results of the pilot areas, tax decrease average ratio of small-scale taxpayers reached $40 \%$. The result is consistent with purpose of tax reform. The tax reform has effectively promoted the development of the tertiary industry, especially the service industry, and promoted the optimization and upgrade of China's industrial structure. However, there are still some companies that feel the tax burden is higher than before.

\subsection{The Tax Burden of Logistics Enterprises does not Drop in Reality}

The original intention of the policy is to reduce the tax burden on enterprises, and guide enterprises to upgrade industries. However, in the implementation process, due to the characteristics of some industries and the limitations of the policy itself,the tax burden of some logistics enterprises does not drop. In these industries with increased tax burden, the tax burden of the logistics industry has risen in the pilot reform. In the investigation and analysis of 65 large logistics in Shanghai. China Federation of logistics and purchasing found that 65 large logistics enterprises in the "camp changed to increase" policy before implementation, the actual tax rate of sales tax is $1.3 \%$, and the actual tax burden of goods transportation enterprises rate is $1.88 \%$. However, after the implementation of the tax reform, the actual tax burden of goods transport enterprises rose to $4.2 \%$. It can be said that the results for the logistics business is unbearable. Because the logistics industry has higher operating costs than other industries, the low level of profits, coupled with the rising tax burden, which for some logistics enterprises is a bad result.

\section{AN ANALYSIS OF THE CAUSES OF HIGHER ENTERPRISE TAX BUEDEN}

The original intention of tax reform is to effectively reduce the tax burden of logistics enterprise. However, 
from the feedback results of some pilot enterprises, the tax burden of some enterprises has not dropped as expected, there has been a sharp rise. The main reason for the emergence of this phenomenon is the following:

\subsection{Higher Tax Rate}

China's current value-added tax has two tax rates, namely, the standard tax rate of $17 \%$ and the low tax rate of $13 \%$. After the tax reform, the VAT added two tax rates of $11 \%$ and $6 \%$. Among them, the transportation industry applies $11 \%$ VAT rate, and the logistics auxiliary service applies the VAT rate of $6 \%$. The original tax rate of the logistics auxiliary service is $5 \%$, and the current VAT rate is $6 \%$. The enterprise will realize the effect of tax reduction on the input tax as long as it is slightly deductible. Before the tax reform, the business tax rate of the transportation industry was 3\%. After the tax reform, the VAT rate was $11 \%$, and the tax rate rose by $8 \%$. If the enterprise wants to keep the tax burden unchanged or decline, the input tax deduction level must reach $8 \%$.As can be seen, the tax rate of the transport enterprises has increased substantially in this tax reform, which is the main reason for the rising tax burden of some logistics enterprises.

\subsection{Unreasonable Input Tax Deduction}

The VAT tax is deductible for tax payable method, which is equal to the output tax minus input tax. After the tax reform, the logistics industry's tax rate rose sharply. In order to achieve the tax reduction target, it is necessary to have a larger deduction on the input tax. However, in the current input tax deductible system, the logistics enterprises have some cost that can not be deducted.

Most of the existing logistics enterprises in our country have been transformed from the original transportation enterprises. Their main input is the vehicle, and most of these vehicles were bought before the tax reform. According to the input tax regulations of the logistics industry, the original vehicles of enterprises can not deduct the input tax after tax reform, which leads to an increase in corporate tax burden. There are many domestic logistics enterprises whose main business is road transportation. According to statistics, about the cost of road transport enterprises, Luqiao accounted for about $35 \%$ of the cost, and labor costs accounted for about $15 \%$. These two items are not deductible in the input tax.

\subsection{Part of VAT Invoices can not be Obtained}

According to the Provisional Regulations on value-added tax, enterprises need to obtain VAT invoices to realize the VAT input tax deduction. However, part of the cost of logistics enterprises is not always able to obtain VAT invoices. Fuel costs are a large part of the cost of many logistics enterprises. However, during the operation of the vehicle in the event of refueling, some gas stations can not provide value-added tax invoices. So, this part of the cost will not be deductible. Transportation equipment is a relatively large part of fixed assets invested by logistics enterprises, and it is an important part of enterprise cost. But most of the logistics enterprises have their own vehicles, and the new purchase of transport equipment is rare. The original means of transport can not be deducted. This caused the logistics company's input tax deductible amount dropped substantially, so that the tax burden does not fall back.

\subsection{Countermeasures of logistics enterprises}

\subsubsection{Flexible Use of Two Kinds of Taxpayer Status}

During this tax reform, value-added tax taxpayers are divided into two categories. One is small-scale taxpayers, the other is general taxpayers. There is a great difference between the two methods of Taxation. The small-scale taxpayers pay VAT according to $3 \%$ of the turnover, and the average taxpayer is taxed according to the general method of taxation.

There is obviously a threshold for how to distinguish between what taxpayers should be choosed.

The VAT formula for two taxpayers is listed:

$$
y_{1}=a * 3 \%
$$

$y_{1}$ is the VAT of small-scale, a is saleroom.

$$
y_{2}=a * 11 \%-b * 17 \%
$$

$y_{2}$ is the VAT of the average taxpayer, $\mathrm{b}$ is the deductible amount.

If the above two types are equal, the deductible amount at this time is equal to $47.06 \%$ of the taxable saleroom. Thus we can conclude that when the deductible input amount is greater than the taxable sales of $47.06 \%$, tax burden of the general taxpayer is less; when the deductible input amount is less than 47.06\%, tax burden of the small-scale taxpayers is less. At this point, eligible enterprises can choose the status of taxpayers according to their own business characteristics, so as to reduce the tax burden.

\subsubsection{Taxable Enterprise should Obtain VAT Invoices as much as Possible}

VAT invoices are the vouchers that enterprises can obtain input tax deductions, so enterprises should do their utmost to obtain VAT invoices when purchasing materials or services. As far as possible with the general taxpayer business cooperation, which is conducive to access to value-added tax invoices. When it is necessary to cooperate with small-scale taxpayers, enterprises should do their utmost to obtain VAT invoices. Basig on their operation characteristics, enterprises should outsource some non-core business to the more professional enterprise that can issue VAT invoices, which can increase the amount of value-added tax deductible input tax items.

\subsubsection{Reasonable Division of Business Types}

According to Article 1 of Annex 2 of the Finance and Taxation [2013]: When enterprise sales of goods or taxable services at different rates, enterprise shall accounte for turnover separately at different tax rates. If the sales amount is not accounted for separately, the tax shall be levied at the highest tax rate that applicable to the various businesses in which they operate. In the payment of taxes, if the company did not separate sales, 
they will be flat to increase the tax burden of enterprises. If the sales amount of the high tax rate is divided into the sales amount at the low tax rate due to the business definition, they will be suspected of tax evasion. In order to avoid the problem of tax rate confusion due to unclear business definition and reduce the tax risk of enterprises, enterprises should classify business types rationally.

\section{POLICY SUGGESTIONS OF TAX REFORM IN LOGISTICS INDUSTRY}

\subsection{Strengthen Market Regulation}

After tax reform, because some rules and regulations are not perfect, some illegal enterprises are given an opportunity to evade taxes. In order to reduce the value-added tax, some enterprises increase the tax amount falsely to reduce the tax burden. For example, the VAT rate for small-scale taxpayers of transportation business is $3 \%$, but, the party that has business dealings with them can use these invoices to deduct the input tax from $7 \%$. The balance of $4 \%$ will undoubtedly be the goal of some illegal enterprises to pursue their interests. In order to reduce the tax burden, some illegal enterprises collude with the enterprises which have no business dealings to issued VAT invoice to offset the input tax. Therefore, the tax authorities should strengthen market supervision and avoid the loss of State Revenue.

\subsection{Reasonable Adjustment of Tax Rate}

In this tax reform, the tax rate of the logistics industry has been greatly changed. The tax rate of logistics and transportation business has increased from $3 \%$ to $11 \%$, and the tax rate has increased considerably; The logistics assistance industry's tax rate has been adjusted from $5 \%$ to $6 \%$. As can be seen, after the tax reform, the tax rate of the logistics industry has improved. This is also the main reason why the tax burden of the logistics industry has not declined. According to the characteristics of high cost and low profit of logistics industry, in terms of tax rates in the logistics industry. The state tax authorities may reduce the tax rate of the logistics industry reasonably according to the actual situation, so as to effectively reduce the tax burden of the logistics industry

\subsection{Extend Deductible Range}

According to the functional classification, Logistics costs include transportation costs, warehousing costs, packaging costs, handling costs, circulation processing costs and so on. Specifically, it includes vehicle depreciation, depreciation of equipment, transportation equipment purchase or leasing, staff salaries, maintenance costs, fuel costs, the cost in Luqiao. Among them, the cost that accounted for a larger proportion of logistics enterprises can not be deducted. In accordance with the characteristics of the logistics enterprises, the tax authorities should rationally expand the scope of input tax deduction, and improve various rules and regulations so as to benefit the enterprises.

\subsection{Encourage Logistics Outsourcing}

Most of traditional business have their own logistics system, but this mode has a lot of shortcomings, which is high cost and low return. In the tax reform, the tax authorities may consider setting up some preferential tax policies to encourage the traditional enterprises to peel their own logistics resources and integrate them into the specialized logistics enterprises. As a result, the traditional enterprises can not only concentrate limited resources to their own core business, for the logistics industry, it can also expand the logistics demand, and promote the development of the logistics industry. For example, when the traditional enterprises transfer corporate vehicles to logistics enterprises, the tax department can consider to exempt VAT. These measures can promote the logistics industry toward specialization and integration.

\section{CONCLUSIONS}

From the actual situation, the tax reform increased the burden of the logistics industry in a certain extent. But in the long run, tax reform can promote the logistics industry towards modernization, informatization and integration, which is conducive to the long-term and healthy development of the logistics industry. Logistics enterprises should take advantage of this opportunity to adjust their own business, so that enterprises can develop healthily.

\section{REFERENCES}

[1] Anthony, D. Ross, Hamieda, Parker, M., Mar, Benavides-ESpinosa, Cornelia, Droge, 2012. Sustain Ability and supply chain infrastructure development, Management decision. 50(10), pp.1891-1910.

[2] Dongming, Xia, 2014. On Planning of Third-party Logistics, Taxation on the Background of Business tax Transforming Value-added Tax, Journal of Huaihua University. 33(09), pp.87-91.

[3] Jiehe, Cui, 2010. Introduction to Logistics, Peking University Press. Beijing, 4th edition.

[4] Jianping, Wang, 2014. "Replace the Business Tax with a Value-added Tax" Should Pay Attention to Taxpayers' Tax Burden and Management Efficiency, taxation research. (01), pp.48-51.

[5] Liming, He, 2011. Implement the Opinions of the General of the State Council on the Policies and Measures for Promoting the Sound Development of Logistics Industry to Promote the Sound Development of Logistics Industry, China Business and Market. 25(11), pp.11-14.

[6] Oskar, Henkow, Andreas Norrman, 2011. Tax aligned global supply chains Environmental Impact illustrations, International journal of physical distribution \&logistics management. 41(9), pp.42-47.

[7] Xi, Feng, 2012. Influence of Change of Business Tax into VAT on Logistics Industry, Logistics Technology. 31(23), pp.177-178. 